\title{
Literacy, Learners and Laws: A Turkish case study of surviving regulation
}

\author{
ÖZLEM ÜNLÜHISARCIKLI
}

\begin{abstract}
This article begins with a systemic overview of the historical background of literacy education in Turkey from the beginning of the Turkish Republic in the 1920s to the present day. The middle part of the discussion focuses on the legal basis of adult literacy and basic education, the programs that are in use, and the accountability and assessment systems. Finally, a qualitative study illustrates how these systems apply to the everyday practices of adult literacy education in Turkey.
\end{abstract}

\section{Introduction}

Adult literacy as an issue goes back to the first days of the Turkish Republic and the early experiences are of a unique kind worth reviewing in summary before passing to the contemporary situation in Turkey. The Republic of Turkey was established over the ruins of the Ottoman Empire in 1923 and adult education, especially the provision of literacy education, was considered to be a panacea to the uneducated and war-weary masses. This was especially true of rural areas. It was also seen as an opportunity to build a sense of national identity around five central grand missions: Modernisation, Industrialisation, Nation Building, Secularisation, and Democratisation. Mass educational provision was seen as a mechanism to break away from the past traditions of the Ottoman Empire by embracing and spreading these new policies.

Immediately after the foundation of the Turkish Republic, the enactment of the Law on Unification of Education No. 430 in 1924 was a landmark, replacing the religiously dominated school system with the secular school system and ending the historical duality between secular and religious education in the country. This Law brought all schools under the Ministry of Education in order to stimulate a national culture and assure national unity in all educational institutions, including adult education.

In 1927, the first population census revealed that in the newly established Republic only about $9 \%$ of the whole population (1.1 million out of a population of 13.6 million) knew how to read and write in the Arabic alphabet that was then in use in Turkey (Oğuzkan 1955). This led to a language reform and the adoption of a new alphabet in 1928. The new 
Turkish Alphabet was based on Latin letters (with 29 letters: 8 vowels and 21 consonants) and replaced the Arabic alphabet that had been in use for a thousand years. This language reform necessitated literacy education for the whole nation therefore, following the alphabet reform, Nation Schools were founded and a nationwide campaign for literacy was initiated (Duman and Williamson 1996).

It was mandatory for everyone between the ages of 16 and 45 to attend these schools. The Nation Schools provided literacy courses and citizenship courses to over one-and-a-half million people in 1928 alone (Şavlı 1974). Nation Schools came to an end in 1936 and their role was assumed mainly by the People's Houses until 1951 (Celep 2003).

There have been many further literacy campaigns and activities since the initial campaign in 1928. Between 1959 and 1975 the Turkish Armed Forces provided literacy education in Private Literacy Schools (Öz 2002). In 1962 a literacy campaign for women was undertaken, and between 1971-1974 activities to support functional literacy occurred. More recently a mass literacy campaign was conducted between 1981-1983 with about three million people participating (Kirazoğu 2003), a new literacy campaign was launched on World Literacy Day in 1992, and a literacy campaign targeting female illiteracy was initiated in 1997. Another literacy campaign, initiated in 2001 by the wife of the then President with the slogan 'Support to National Education,' aimed to reach two million people (Bilir 2007) and started a trend for literacy as the favoured cause of female spouses of politicians (oddly reminiscent of the United States!). A campaign with the slogan 'Turkey is Literate' was launched in early 2008 by the wife of the President and finally, September 2008 was the launch date for the latest literacy campaign-initiated by the wife of the Prime Minister and bearing the slogan 'Mother Daughter in School'. As in the English-speaking world, the pattern is one of constant rediscovery of a literacy 'crisis' (Quigley 1997). 
Despite all the efforts, the overall illiteracy rate in Turkey is still about $11.8 \%$ and literacy education will remain a major task in the coming years. Moreover, there is a gender gap (the overall illiteracy rate for males is $4 \%$, whereas it is $19.6 \%$ for females), and a regional gap (overall illiteracy rate is $8.7 \%$ in urban areas, and $17.3 \%$ in rural areas) (Table 1).

\begin{tabular}{lrrrrcccc}
\hline & \multicolumn{3}{c}{ Total Turkey } & \multicolumn{2}{c}{ Urban Areas } & \multicolumn{2}{c}{ Rural Areas } \\
\cline { 2 - 8 } & Total & Male & $\begin{array}{c}\text { Fema } \\
\text { le }\end{array}$ & Male & $\begin{array}{c}\text { Fema } \\
\text { le }\end{array}$ & Male & Female \\
\hline Illiterate & 6.139 & 1.026 & 5.113 & 454 & 2.402 & 571 & 2.712 \\
Literate & 3.435 & 1.341 & 2.094 & 678 & 1.116 & 663 & 978 \\
$\begin{array}{l}\text { Primary education } \\
\text { General }\end{array}$ & 28.794 & 15.146 & 13.649 & 9.071 & 8.483 & 6.075 & 5.166 \\
$\begin{array}{l}\text { Secondary } \\
\begin{array}{l}\text { Vocational } \\
\text { Secondary }\end{array}\end{array}$ & 5.584 & 3.233 & 2.351 & 2.431 & 1.857 & 802 & 494 \\
Higher Education & 3.810 & 2.460 & 1.350 & 1.802 & 1.092 & 658 & 258 \\
\hline \multicolumn{1}{r}{ Total } & 51.668 & 25.601 & 26.067 & 16.447 & 16.271 & 9.154 & 9.797 \\
\hline
\end{tabular}

Table 1. Population by education level in 2006: 15 years old and over (numbers are in thousands). Adapted from TURKSTAT (2007).

In the Turkish context 'illiterate' means that a person does not know how to read and write in their mother tongue. 'Literate' means a person knows how to read and write, but they may or may not possess credentials. However, considering a person as illiterate or literate depends on selfidentification, and the number of illiterate people may be even higher. Some people declare themselves as 'literate' because they are ashamed to label themselves as 'illiterate'. Table 1 shows the population broken down both by literacy and by the credentials they hold.

\section{Legal basis of adult literacy and basic education}

The early efforts in literacy education provided a structure and organisation to adult literacy education efforts and shaped the later legal framework and practices. Accountability for adult literacy education in Turkey is mainly concerned with compliance with laws and regulations, rather than the 'quality' of provision as such. The legal situation is not simple, but in the following section I lay out some of the key laws and regulations relating to adult literacy education.

The Turkish educational system is divided into formal and non-formal education by the Basic Law on National Education No. 1739 of 1973, with Articles 40, 41, and 42 covering non-formal education. Non-formal education covers all kinds of educational provision, including adult literacy education, to 
address the educational needs of every individual over the age of 14 regardless of educational background. The main responsible body in nonformal education is the Ministry of National Education (MoNE), General Directorate of Apprenticeship and Non-Formal Education. The educational system is very centralised in Turkey and the educational provision of all state, private, and voluntary bodies is run under the monitoring and inspection of MoNE.

The specific responsibilities for adult literacy education provided under the auspices of MoNE are regulated by the 1983 Literacy Training for Citizens who are Out of the Compulsory Primary Education Age Law No. 2841. Accordingly, there is a Department of Literacy under MoNE, General Directorate of Apprenticeship and Non-Formal Education responsible for program development and evaluation on adult literacy education. The Department of Literacy is a very small unit with only one expert and a couple of secretaries working to accomplish the immense requirements of literacy education (Nohl and Sayllan 2004). According to this Law the responsibilities of the General Directorate for adult literacy education are:

- organising all kinds of educational activities;

- providing cooperation and coordination with the state organisations and private and voluntary organisations;

- monitoring and inspection of the educational programs and activities;

- providing educational staff, material and technical support;

- assisting the educational activities of other organisations by means of advising and taking necessary measures;

- giving certificates and diplomas who complete the literacy courses with success; and

- taking measures to motivate the state personnel and the like (Article 4).

The responsibilities of the private sector are also determined by this Law. Private sector institutions are obliged to take the measures to provide literacy education for their workers either by sending them to literacy courses provided by MoNE or establishing in-house literacy courses (Article 6).

The law is supported by two significant regulations. They are MoNE Non-formal Education Institutions Regulation and the Regulation on Courses to be Offered Free of Charge by Public Institutions and Organisations, Municipalities, Foundations, Associations, and Vocational Chambers under Control of MoNE (both published on 14 February 2006, Official Gazette 26080). These two regulations state the rules for administration, procedures, and guidance of literacy educational activities offered in Turkey. These laws and regulations apply to all adult literacy education providers without exception. It is clear that the intention is to create a highly centralised and consistent adult education system throughout the nation. 


\section{Adult literacy and basic education programs}

Until 1980, adult literacy programs were concerned with teaching how to read and write, supporting basic skills and primary school completion programs. After 1980, these programs were re-invented as Level I and Level II by MoNE. The programs were designed along behaviourist lines, and the teaching technique was based on memorising whole sentences first and learning sound-letter correspondences later. This remarkably strong commitment to a radical 'whole language' approach ended in 2005, when, as suggested in the Support to Basic Education Program (MoNE 2007a), new programs for Level I and Level II were developed. Their curricula were based on a constructivist approach, in line with the primary school curriculum, which was considered better suited to the needs of the target population (MoNE 2007b).

Most adult literacy education is directly provided by the MoNE in state-funded Public Education Centres (PECs) established in 1955. PECs are the main providers of adult education courses among the institutions run by the MoNE General Directorate of Apprenticeship and Non-formal Education. In the 2006-2007 academic year alone, 204,747 participants attended adult literacy education in PECs (MoNE 2008a). PECs also cooperate with other state institutions in providing literacy education to the public, such as the Turkish Armed Forces and Ministry of Justice, as well as NGOs such as Mother-Child Education Foundation (MOCEF), Rotary Club, and Association for Supporting Contemporary Life. Among these institutions only MOCEF and the Rotary Club have their own literacy education curricula equivalent to Level I and approved by the MoNE. These are the Functional Adult Literacy Program, and Simplified Literacy Education Program respectively (Nohl and Saylan 2004).

The objectives of Level I include teaching adult participants how to read and write, making them more proficient in written and spoken Turkish, teaching them basic mathematics, and helping them to acquire basic knowledge, skills and behaviours to be used in their daily lives. The Level I course is considered equivalent to the third grade of the eight-year Turkish primary education, and is planned as 90 class hours, though the duration may be extended to 120 hours if needed. Level I courses can be delivered in PECs or, with MoNE's approval, in any other place chosen by one of the NGOs. Participation is free of charge and the teaching-learning materials are also provided for free by the local PEC. It is possible to open a Level I course with only two participants. Those who successfully complete a Level I literacy program get the right to continue to a Level II literacy program.

No matter which agency provides the materials or the curriculum for programs equivalent to Level I, it is the responsibility of the PECs to offer the certificates to the participants upon successful completion. However, 
assessment of the participants for Level I and equivalent programs is the responsibility of the course teacher, and there is no standardised test system to assess the learner outcomes.

Level II courses are only offered at PECs by teachers who are appointed by the MoNE, and no other institution or organisation is allowed to organise this level of course. Level II aims to offer education that is equivalent to the fourth and fifth years of primary schooling and, again, the participants receive a certificate upon successful completion. With the Level II certificate it is possible to enrol in open primary education and to earn a primary school diploma after successful completion of three more years of schooling. The Level II program is 180 hours and organised around four different courses: Turkish, Basic Social Sciences, Science and Technology, and Mathematics (MoNE 2007b).

Assessment of participants at Level II is the responsibility of an exam commission. The teacher in charge of the Level II program prepares the exam and the commission is responsible for administering the exam, keeping the records, and preparing the relevant documents and paper-work. Like the Level I program, there is no standardised test system to assess the learner outcomes, but in this case responsibility for assessment goes beyond the individual instructor.

\section{The policies in practice}

As the previous sections have shown, adult literacy education in Turkey is seen as an important activity, contributing to nation-building and the creation of economic and gender equity. Legally, it is highly centralised, at least on the level of curriculum, but highly diverse in terms of assessment and, with instructors who receive little training, it is likely to be highly diverse in everyday practices as well. However, there is no research that explores how the laws and regulations interact with the everyday practices of adult literacy education practitioners. Therefore, this article collects views and attitudes of teachers related to their adult literacy education practices, providing important insights into accountability and assessment of adult literacy education in Turkey.

To investigate whether there is a discrepancy between the practices of teachers and the laws and regulations in use, and if so, what they are, a qualitative method has been used in this study. The MoNE teachers and directors who are involved in adult literacy education in Istanbul constitute the target of the study. They were, recruited through convenience sampling. Currently, there are 39 administrative districts in Istanbul, and in each district there is one PEC. In order to contact practitioners in literacy education I phoned PECs and talked to the directors and the literacy instructors who were available at the time of the study, in Summer, 2008. Since it was Summer time and most of the practitioners were on their Summer vacations 
and the others were busy it was difficult to get appointments from the practitioners. I had to call back most of them several times until I got scheduled appointments. I interviewed a total of ten practitioners (altogether three directors and seven teachers) from four different PECs and a primary school that offered literacy education to adults in cooperation with the local PEC. Except for one of the respondents, who has been teaching for six years as a primary school teacher but offering adult literacy courses only for two years, the other respondents had at least 15 years of experience in adult literacy education. Of the seven teachers, three were teaching at Level I and four were teaching at Level II.

The interviews were semi-structured, and investigated the daily practices of literacy instructors and whether these practices differed from what the regulations necessitated. The duration of interviews varied from half an hour to two hours, and generally took place in the offices of teachers and directors. Since they were busy with administrative duties and registration processes for the coming courses there were occasional disruptions. Moreover, tape-recording was not possible, so that during interviews I took extensive notes to avoid loss of data. In fact, the interviewees were quite conscientious about the interview process and sometimes stressed very strongly that I should specifically note down what they were saying in their exact words. I coded the interviews and then grouped similar codes together and created categories. Then I undertook a cross-case analysis of the interviews according to these broad categories, which reflected a common perspective on conforming (or not) to the processes dictated by the regulations. Therefore, the data is laid out in the four thematic areas explored in the interviews: duration of the programs, attendance of the participants, assessment of the participants, and the teachers' views of the curriculum. The quotes selected are either the ones that represent broadly similar views or the ones that reflect atypical views. In the reporting, names of the interviewees have been changed to protect particpants' identities.

\section{Duration of the programs}

All program evaluation studies revealed that the duration of Level I and equivalent adult literacy programs has always been a problem throughout the years in Turkey, with programs tending to be too short for maximum effectiveness (Durgunoğlu, Öney and Kuşçul 2003, Bülbül et al 1999). The practitioners interviewed in this study also mentioned the same problem, but they also indicated the ways they found to deal with this problem. For instance, Mustafa, who offers a Level I program, provides extra hours for the participants if needed:

Originally it was 90 hours, now we can extend it to 120 hours.

But it is still not enough. Okay, perhaps it is enough for some, but for most of the participants, especially for the elder ones, 
it is not enough. Some cannot even learn how to hold a pencil properly. I do some extra hours for those in need of them.

But I am doing this without getting any credit.

Time is also a problem for Level II programs, and Emre offered a different solution:

Level II is equivalent to the fourth and fifth grade at primary

school. Can you imagine, you are trying to cover the

curriculum of two-years in just 180 hours? It is not possible.

What I do is this; I look at the profile of the course

participants and decide which parts of the curriculum to cover

and which parts to leave out. Otherwise, you cannot do it.

Although there is a common agreement that the duration of courses is too short, Mehmet who is a director recognised the difficulty of extending the courses:

The Ministry doesn't want to make the programs longer. But at the same time, extending the courses doesn't seem probable and practical to me. People are already having problems of attendance, if we make the courses longer I am afraid it would de-motivate them to participate from the very beginning.

The duration of the programs is a real problem in terms of day to day teaching, but as Mehmet indicated, simply extending them might not be effective. This presents a real dilemma for administrators and instructors.

\section{Program attendance}

The regulations require attendance on a regular basis, and a participant is allowed to miss only one-fifth of the classes. But all of the practitioners identified attendance as a problem. The teachers said they understand that the participants are adults, that they have other responsibilities, that the time schedule is not convenient for all and many other reasons. Because of these reasons, they indicated that sometimes they find ways to accommodate their students. Mehmet is one of these practitioners and he summarised the situation:

It is difficult for adults to come to the classes all the time, sometimes they have other things to do and we need to be tolerant, otherwise the person would drop-out totally. So sometimes we do not report missed attendance in our reports. You have to do that. The regulations also restrict the time for registration to the courses, but sometimes people want to commence after the official registration time is over. What do I do? I simply accept the person and re-arrange the paperwork. You have to do that, you have to be flexible, if you want to serve these people better. 
Again the teachers observe the participants and try to understand their situation before deciding the appropriate response. But some also reflected upon the difficulty of keeping a balance, because the participants should not be abusing the tolerance of the instructors and there should be fairness. Veysel explained that there had been a very bright student at Level II who was a 5th grade school drop-out and need not come to the classes at all to pass the exam:

I told him not to come to the classes, but this would create disturbance among the other participants so I told them that he is repeating the program from the previous year, since those who repeat the program do not need to attend the classes, they did not say anything. Like this I lied to the other participants and I reported on papers as if he is coming on a regular basis.

But Nadir, another Level II teacher, indicated that the system could be easily abused since the teacher keeps the records and no one inspects those records:

Sometimes people want to bribe us in order not to attend the classes and get the certificate without accomplishing the requirements. I try to be fair and sometimes tolerate missed attendance, but the person has to be successful at the end of the program. But bribery is very disturbing and I suspect some accept.

Nadir also provided an example on the issue. Those who have the Level II certificate are eligible to receive a driving license, but one is required to attend a driving course before receiving the license. As the teacher explained, there had been rumours that some of these courses get Level II certificates for their customers who do not have a school diploma by paying money.

Some motor-vehicle driving courses do not ask the applicants to get the training required, they just get the money and organise the papers and send the papers to the related office and the applicant goes there to fetch the license. In the story, I heard that as usual the traffic-police officer asked the person to write his name and sign up some paper to indicate that he has received the driving-license, and the person could not. So the officer got suspicious and finally found out that the person is illiterate although had the Level II certificate!

Aslan who is in charge of inspecting the motor-vehicle driving courses also emphasised his suspicions related with the issue:

I cannot prove it, but I know as I know my name that some of the teachers are organising certificates to people who have not actually participated in the literacy program. ... The exam commission must also be in it; otherwise, it would not be 
possible for a teacher to do that. If the commission is in it then everything would be organised officially and no one would know.

Attendance is a balance between what is appropriate for the individual learner and the regulations. This is an interesting situation, where the discretion of instructors can compensate for the multiple time demands faced by learners, but can also lead to abuse of the system by the less scrupulous. However, as Emre, a Level II instructor, indicated it is expected that primary school diploma will be required with new regulations to attend the motor-vehicle driving courses. Therefore, it will not be possible to abuse the system in the same way.

\section{Assessment of the participants}

The MoNE Non-formal Education Institutions Regulation indicates that the course teacher has the authority to conduct written, oral, and applied exams for assessment of Level I participants. If the teacher decides the participant is successful at the end of the course then the person gets the certificate from the local PEC. An exam commission is responsible for the summative assessment at Level II, and the written exam is prepared by the program teacher, who takes part in the commission. Teachers generally prepare questions according to the objectives provided in the curriculum of Level I and Level II. Although most of the teachers did not see problem in preparing their own questions a few indicated the difficulty of not having a standardised assessment system. Mustafa is one of those who had difficulty in complying with the regulations.

I try to do everything according to the regulations, but not everything is there. For example, for the exams I prepare my own exams but someone else prepare other questions. So there is no standardisation in this. I may ask difficult questions and someone else may ask easy questions.

Nadir reflected that the level of the questions may change according to the level of the class:

There is the commission but the teacher prepares the questions and many times we prepare our questions to the level of our participants. If the level is high, then the questions would be more difficult; if the level is not so high then the questions would be a bit easier. There is no standard to it. This is how we need to do it. We want to give certificates if the person has made progress.

What Bora said in fact reflected how trivially assessment was considered by some practitioners:

In fact I do this exam thing just because it is required, for me it is a formality. I know by heart who would succeed and who 
would fail. I know my students; I know their levels from our practices in the classroom. I do not need an exam to learn their levels. If I need then I am not a good literacy teacher! Therefore, teachers have quite different views of assessment procedures. Some promote the need for a standardised test whereas others support the teacher autonomy in assessment.

\section{Views of the curriculum}

The interviews revealed that there are various methods used by the teachers. Despite the curriculum change some use their own preferred method; some alter the existing curriculum to fit their purposes better. As the teachers noted, problems related to the curriculum and the teacher guidebooks are that the curriculum is loaded and difficult to cover in the course duration. Guidebooks are provided for teachers, but are not very useful since the number of activities is limited, the instructions are short, and there are not enough examples. Even more importantly, the content of the guidebooks is not parallel with that of the curriculum. Overall, teachers tend to use whatever method they would like to use. Bora is one of them:

According to me, neither the previous curriculum (from sentences to sounds) nor the present one (from sounds to sentences) is suitable to teach literacy. I use my own method; it is a mixture of both and no one asked to this day about my own practice... I don't use the workbooks and other materials prepared and send to us by the Ministry... If I use those materials I cannot teach reading and writing to people.

Nazan, who is a primary school teacher and offering Level I course in coordination with the local PEC is the only instructor that indicated any positive views on the new curriculum, but not without some reservations:

I like the new curriculum, it is better than the previous one. It is good but it is very loaded, time is not enough to cover all those in the curriculum. I can only teach the literacy part, not enough time for mathematics and life skills. You can only teach how to read-and-write, that's all.

The participants also indicated that some kind of inspection would be good, so that problems could be identified. However, the way inspection is done is also considered as important. Currently, the PECs are inspected at the institutional level every two years, but this does not cover the individual programs and instruction. Emre argued that inspection should be introduced back into the system:

There used to be inspection in the previous years but since the new curriculum was put into practice in 2005 there is no inspection because everything is pre-prepared by the Ministry, the course objectives, the activities to be carried during the 
classes, everything. So they assume we use them, but everybody is doing something else and there is no control. Even if there were control in old times we were still doing what we wanted to do, only on paper we used to prepare the course program and lesson plans according to the curriculum and the way the Ministry wanted and inspections were done mainly by checking those plans rather than what is going on actually in class. I do what is good for my course participants and they are not in the curriculum always.

The curriculum, the teacher's guidebooks, and all other material are prepared by the MoNE Department of Literacy. Bora criticised the administrators who are in charge of the Department of Literacy at the Ministry:

It is not possible to do this properly sitting at the office in Ankara. They should first have some field experience, have some experience in teaching how to read and write to adults. Then, they would talk.

Aslan reflected about the experts in the commission that prepared the Level I and Level II curriculum:

One or two people from the Department of Literacy at the Ministry are experts and dedicated but not all. I have also met those people who prepared the workbooks, at one of the meetings organised by the Ministry. To me, they are all academics who do not have experience in teaching illiterate adults. We, teachers should also have taken part in preparing those materials.

Nazan emphasised that usually teachers do not remember that a Department of Literacy existed in Ankara.

We do the things as we always do, many of us do not even know that there are some people at the Ministry.

As mentioned earlier, the MoNE Department of Literacy is a small unit that is responsible for program planning, curriculum development, providing materials, organising volunteers' training, and any other adult literacy education related tasks and duties. During the development of new curriculum there were some difficulties. Since there was no financial support it had been difficult to find volunteers to work in the committee to develop the curriculum. Expertise in adult education and literacy was needed besides program development, and it had not been possible to find commission members who had such expertise (Nohl and Saylan 2004).

The practitioners consulted here appear to have some fairly significant concerns about the curriculum. The materials are not always consistent and the lack of inspection, in the positive sense, and professional support appears to be keenly felt. 
A related concern is the fact that teachers of adult literacy and basic education programs do not have any in-depth preparation in adult education. MoNE teachers who provide Level I and Level II courses are usually teachers who have primary school teaching diplomas and are supposed to know how to teach reading-and-writing to adults from their practice with children. MoNE did not have a specific teacher training program in teaching adults for these teachers. In 2008 a teacher training framework program, named 'Adult Literacy Instructional Techniques Course' was being prepared to introduce the MoNE teachers to the latest curriculum, instructional techniques, teaching material, assessment and evaluation. The inaugural course was planned to take place in June 2008 with 50 MoNE teachers participating (MoNE 2008b). However, this program did not happen, and has been postponed to an indeterminate date. Therefore, it can be argued that the system has not yet established mechanisms for curricular accountability and professional development.

\section{Conclusion}

Turkey has a long tradition of adult literacy education, and current practices have their roots in earlier practices despite the periodic updates of legislation, regulation and approach. The Law on Unification of Education enacted in 1924 requires all adult literacy programs to be under the control of the MoNE General Directorate of Apprenticeship and Non-formal Education. Accountability to this agency is maintained by a complex and highly systemised system of laws and regulations, which provides a framework for all adult literacy education-whether it is directly provided by MoNE or an approved program provided elsewhere. The nominal degree of centralisation espoused in Turkish adult literacy education is remarkable and certainly unusual.

However, despite this centrality and laws and regulations the Department of Literacy under the MoNE General Directorate of Apprenticeship and Non-formal Education is a small unit that has to deal with the huge task of planning, co-ordination, and evaluation of literacy programs and campaigns. Perhaps the responses of the practitioners to this system, which has been illustrated through the comments included here, are partly a consequence of the almost invisible existence of the strong central office in such a centralised system. Responsibility is highly centralised, but practicalities make for very 'light touch’ monitoring.

In each of the areas of duration, attendance, assessment, and curriculum there is a tension between the pressure to meet the demands of centralisation and the desire to personalise teaching structures to reflect learner's needs. This is not unusual in any system, but the particular form of these tensions in the Turkish context is extremely interesting. The instructors are striving for means of providing the needs of their learners but there is no 
substantial research study that determines the strengths and weaknesses of the existing system. Suggestions of starting points for dealing with the tensions bearing on instructors include providing more professional support to the instructors; introducing some flexibility into the system to adapt the individual programs to the learning needs of participants; evaluating literacy training techniques currently in practice and determining the problems that are faced to develop new course materials and resource books; and restructuring the Department of Literacy as a larger unit equipped with more resources and professional staff. 


\section{References}

Bilir, M (2007) Non-formal Education Implementations in Turkey: issues and latest challenges, International Journal of Lifelong Education, 26 (6), 621-633.

Bülbül, S, Kavak, Y, Gülbay, Ö, Gelbal, S, Ekinç, E, Gökçe, F, Burgaz, B, Badavan, Y and Üstünda, T (1999) A Research on the Evaluation of the First Level Literacy Courses in Turkey (Final Report), MoNE and Turkey Office of UNICEF, Ankara.

Celep, C (2003) Halk E itimi, Anı Yayıncılık, Ankara.

Duman, A and Williamson, B (1996) Organisation, Constraints and Opportunities: An analysis of adult education in Turkey, International Journal of Lifelong Education, 15 (4), 286-302.

Durguno lu, A Y, Öney, B and Kuşççul, H (2003) Development and Evaluation of an Adult Literacy Program in Turkey, International Journal of Educational Development, 23, 17-36.

Kirazoğlu, C (2003) An Evaluation of Adult Literacy Campaigns in Turkey, unpublished dissertation, Boğaziçi University, Istanbul

MoNE (2007a) Support to Basic Education Program: Strategic report (Final Draft), MoNE, Ankara.

MoNE (2007b) Yetişkinler Okuma Yazma Öğretimi ve Temel Eğitim Programı (I. Ve II. Kademe), MoNE General Directorate of Apprenticeship and Non-formal Education, Ankara.

MoNE (2008a) Çıraklık ve Yaygın $\boldsymbol{E}$ itim Genel Müdürlügü: Türkiye geneli Halk Eğitim Merkezleri sayısal verileri. Available online: http://cygm.meb.gov.tr/birimler/istatistik/hem/hemistat.htm (accessed July 2008).

MoNE (2008b) Hizmetiçi Etkinliği Çerçeve Programı, MoNE, Hizmetiçi Eğitim Dairesi Başkanlığı. , retrieved July 2008 from http://hedb.meb.gov.tr/faaliyet/liste/2008317p.htm.

Nohl, A M and Saylan, F (2004) Teaching Adult Literacy in Turkey: Technical Report to the Support to Basic Education Program, MoNE/EU, Ankara.

Oğuzkan, T (1955) Adult Education in Turkey, UNESCO, Paris.

Öz, M (2002) Türkiye Cumhuriyeti’nde Okuma-Yazma Seferberlikleri ve Yönetimi, Anadolu University, Eski ehir.

Quigley, B A (1997) Rethinking Literacy Education: The critical need for practice-based change, Jossey-Bass, San Francisco.

Şavlı, B (1954) Adult Education in the Democratic State of Turkey, unpublished dissertation, Indiana University, Bloomington.

Turkstat (2007) Household Labour Force Statistics: 2006, Turkish Statistical Institute, Ankara. 